PERTANIAN

\title{
PENGARUH PEMBERIAN PUPUK KALIUM DAN HORMON GIBERELIN TERHADAP KUANTITAS DAN KUALITAS BUAH BELIMBING TASIKMADU DI KABUPATEN TUBAN
}

\author{
Effect of Potassium Fertilizer and Giberelline Hormone on Quantity and \\ Quality of Tasikmadu Starfruit in Tuban Regency
}

Nur Wijiyanti dan Raden Soedradjad*

\author{
Program Studi Agroteknologi, Fakultas Pertanian Universitas Jember \\ Jl. Kalimantan 37, Kampus Tegal Boto, Jember 68121 \\ *E-mail: soedradjad.faperta@unej.ac.id
}

\begin{abstract}
Tuban Regency is an Agropolitan area that develops Tasikmadu starfruit plants. The demand form Tasikmadu starfruit has increased every year but it cannot be fullfilled because of the low production in terms of quantity and quality. The problem is the fruit size is small and the productivity is low. These problems can be overcome by the use of potassium fertilizer and gibbereline hormone. Giving potassium fertilizer and gibereline hormone is expected to increase the production of Tasikmadu starfruit plants in Tuban Regency. The results of this study can be used as a reference in the administration of potassium fertilizer and gibbereline hormone in the cultivation of Tasikmadu starfruit plants in Tuban Regency. This study uses factorial Randomized Block Design (RBD). The first factor is the dose of potassium fertilizer with 4 levels of $\mathrm{KCl}$ fertilizer dose which is $0 \mathrm{~g} / \mathrm{plant}, 150 \mathrm{~g} / \mathrm{plant}, 300 \mathrm{~g} / \mathrm{plant}$ and $450 \mathrm{~g} / \mathrm{plant}$. The second factor is the concentration of gibberelin hormone which consists of 4 levels, which is $0 \mathrm{ppm}, 50 \mathrm{ppm}, 100 \mathrm{ppm}$ and $150 \mathrm{ppm}$. The data obtained were analyzed by using standart error minimum.
\end{abstract}

Key words: Tasikmadu Starfruit, Potassium Fertilizer, Gibbereline Hormone.

\begin{abstract}
ABSTRAK
Kabupaten Tuban merupakan daerah Agropolitan yang mengembangkan tanaman Belimbing Tasikmadu. Permintaan belimbing tasikmadu mengalami peningkatan setiap tahunnya namun belum dapat dipenuhi karena rendahnya produksi belimbing tasikmadu dari segi kuantitas dan kualitas. Masalahnya adalah ukuran buah yang kecil dan rendahnya produksi.. Masalah-masalah tersebut dapat diatasi dengan penggunaan pupuk kalium dan hormon giberelin. Pemberian pupuk kalium dan hormon giberelin diharapkan mampu meningkatkan produksi tanaman belimbing tasikmadu di Kabupaten Tuban. Penelitian ini bertujuan untuk mengetahui pengaruh kombinasi perlakuan pupuk kalium dan hormon giberelin terhadap produksi tanaman belimbing tasikmadu di Kabupaten Tuban. Hasil penelitian ini dapat dimanfaatkan sebagai acuan dalam pemberian pupuk kalium dan hormon giberelin pada budidaya tanaman belimbing tasikmadu di Kabupaten Tuban. Penelitian ini menggunakan Rancangan Acak Kelompok (RAK) faktorial. Faktor pertama adalah dosis pupuk kalium berupa $\mathrm{KCl}$ dengan 4 taraf yaitu 0 gram/tanaman, $150 \mathrm{gram} / \operatorname{tanaman}, 300 \mathrm{gram} / \operatorname{tanaman}$ dan $450 \mathrm{gram} / \operatorname{tanaman}$. Faktor kedua adalah konsentrasi hormon giberelin yang terdiri dari 4 taraf yaitu 0 ppm, 50 ppm, 100 ppm dan 150 ppm. Data yang diperoleh dianalisis menggunakan analisis simpangan baku terkecil.
\end{abstract}

Kata kunci : Belimbing Tasikmadu, Pupuk Kalium, Hormon Giberelin

How to citate: Wijiyanti, N., Soedradjad, R. 2019. Pengaruh Pemberian Pupuk Kalium dan Hormon Giberelin terhadap Kuantitas dan Kualitas Buah Belimbing Tasikmadu di Kabupaten Tuban. Berkala Ilmiah Pertanian 2(4): 169-172.

\section{PENDAHULUAN}

Kabupaten Tuban terletak pada 6,40' sampai 7,18' LS serta 111,30 ' sampai 112,35 ' BT. Tuban berada di sepanjang garis pantai utara. Kabupaten Tuban merupakan salah satu kabupaten di Jawa Timur yang mengembangkan konsep agropolitan pada tanaman hortikultura khususnya belimbing. Kawasan agropolitan kebun belimbing terletak di Kecamatan Palang tepatmya di Desa Tasikmadu. Belimbing yang dikembangkan adalah Belimbing Tasikmadu yang merupakan belimbing lokal atau belimbing asli Kabupaten Tuban. Belimbing Tasikmadu telah ditetapkan melalui Keputusan Menteri Pertanian No.314/KPTS/SR.120/5/2007 tentang pelepasan belimbing varietas Tasikmadu sebagai varietas unggul lokal. Berdasarkan data Badan Pusat Statistik (2017), produksi Belimbing Tasikmadu selama tahun 2016 di Kecamatan Palang yaitu mencapai $1.061 .500 \mathrm{~kg}$ dengan jumlah tanaman 23.243 pohon pada lahan seluas \pm 50 ha. Umur tanaman berkisar 530 tahun. Produktivitas Belimbing Tasikmadu sebesar 45,67 $\mathrm{kg} / \operatorname{tanaman}$.

Belimbing Tasikmadu cocok ditanam di daerah Tuban dengan kondisi lingkungan yang mendukung pertumbuhan tanaman belimbing. Widiatmaka dkk. (2015) menyatakan bahwa berdasarkan data iklim tahun 2004 sampai 2013 Kabupaten Tuban merupakan daerah yang memiliki iklim tropika kering. Temperatur udara di Kabupaten Tuban yaitu $26,6-28,9^{\circ} \mathrm{C}$. Kabupaten Tuban merupakan wilayah dataran rendah dengan jenis tanah yang mendominasi adalah tanah ordo Inseptisol dan Alfisol. Tanah tersebut merupakan tanah muda yang belum berkembang lebih lanjut. 
Menurut Sari (2013), buah Belimbing Tasikmadu yang saat ini beredar di pasaran memiliki berat rata-rata 160 gram. Buah Belimbing Tasikmadu dengan berat 160 gram tersebut termasuk dalam ukuran kecil. Selain ukurannya yang kecil, Belimbing Tasikmadu juga memiliki produktivitas yang rendah yaitu sebesar 45,67 kg/tanaman (Tabel 1.1). Berat buah dan produktivitas Belimbing Tasikmadu tersebut masih berada dibawah potensi Belimbing Tasikmadu. Berdasarkan deskripsi Belimbing Tasikmadu yang terdapat pada Keputusan Menteri Pertanian memiliki potensi berat buah sebesar 200-300 gram dengan produktivitas 200-300 kg/tanaman.

Produktivitas dan ukuran buah Belimbing Tasikmadu mempengaruhi kuantitas dan kualitas produksi Belimbing Tasikmadu, yang dapat ditingkatkan dengan penggunaan pupuk kalium dan pemberian hormon giberelin. Pupuk kalium berfungsi dalam mempengaruhi susunan dan translokasi karbohidrat dalam tubuh tanaman, mempercepat metabolisme nitrogen serta mencegah bunga dan buah agar tidak gugur (Wibowo, 2015). Pupuk kalium juga dapat meningkatkan kemanisan buah. Penambahan pupuk kalium dalam dosis yang tepat dapat meningkatkan kadar gula buah stroberi (Simorangkir dkk., 2017). Sedangkan hormon giberlin sendiri berdasarkan penelitian Gubali dkk. (2017), hormon giberelin yang diaplikasikan secara eksogen pada tanaman ketimun dapat mengurangi jumlah biji yang terbentuk karena hormon giberelin dapat menginduksi buah partenokarpi dan menambah ukuran buah baik itu berat buah maupun panjang buah. Giberelin dapat mempengaruhi terjadinya pembelahan sel sehingga jumlah sel akan bertambah yang mengakibatkan bertambahnya ukuran buah, pembungaan dan pembuahan. Peningkatan konsentrasi hormon giberelin secara langsung akan meningkatkan pembesaran buah.

Berdasarkan uraian di atas maka perlu dikaji tentang pengaruh pemberian pupuk kalium dan hormon giberelin pada tanaman Belimbing Tasikmadu. Oleh karena itu perlu dilakukan penelitian yang bertujuan untuk untuk mengetahui pengaruh pupuk kalium dan hormon giberelin terhadap buah belimbing tasikmadu di Kabupaten Tuban.

\section{BAHAN DAN METODE}

Waktu dan Tempat. Penelitian dilaksanakan pada bulan Januari 2019 sampai dengan April 2019, bertempat di Kebun Belimbing Agropolitan Kabupaten Tuban.

Alat dan Bahan. Alat utama yang digunakan dalam penelitian adalah timbangan, refraktometer, moisture meter, gunting pangkas, botol semprot, jangka sorong, dan alat pendukung lainnya. Bahan utama yang digunakan dalam penelitian adalah tanaman belimbing tasikmadu yang berumur \pm 10 tahun, pupuk $\mathrm{KCl}$, hormon giberelin $\left(\mathrm{GA}_{3}\right)$ dengan nama produk SuperGib dan bahan pendukung lainnya.

Metode Percobaan. Percobaan ini disusun secara faktorial $4 \times 4$ menggunakan pola dasar Rancangan Acak Kelompok (RAK) dengan tiga kali ulangan. Adapun faktor pertama yang diteliti adalah aplikasi dosis pupuk $\mathrm{KCl}$ dengan 4 taraf $(0 \mathrm{~g} \mathrm{KCl} /$ tanaman, $150 \mathrm{~g} \mathrm{KCl} / \operatorname{tanaman}, 300 \mathrm{~g} \mathrm{KCl} / \operatorname{tanaman}$ dan $450 \mathrm{~g} \mathrm{KCl} / \operatorname{tanaman})$ dan faktor kedua konsentrasi hormon giberelin dengan 4 taraf ( 0 ppm, 50 ppm, 100 ppm dan 150 ppm).

Persiapan Alat dan Bahan. Persiapan alat dan bahan tersebut berarti menyiapkan semua alat dan bahan yang digunakan untuk penelitian. Pertama yaitu menyiapkan semua alat yang dibutuhkan lalu menyiapkan bahan yang akan digunakan mulai menyiapkan dan menetapkan tanaman yang akan diperlakukan, menyiapkan pupuk kalium dan hormon giberelin. Menimbang pupuk $\mathrm{KCl}$ sesuai dengan dosis perlakuan yang digunakan dan mengemasnya yaitu $150 \mathrm{~g}, 300 \mathrm{~g}$ dan $450 \mathrm{~g}$. Selanjutnya pembuatan larutan hormon giberelin sesuai dengan konsentrasi perlakuan yaitu melakukan pengenceran dari stok yang dibuat. Produk Giant memiliki persentasi kandungan giberelin sebesar $20 \%$ per $1 \mathrm{~g}$ yang artinya $1 \mathrm{~g}$ mengandung $200 \mathrm{mg} \mathrm{GA} \mathrm{G}_{3}(1 \mathrm{~g}=$ $20 / 100 \times 1000 \mathrm{mg}=200 \mathrm{mg} \mathrm{GA}_{3}$ ). Pembuatan stok dilakukan dengan menimbang $1 \mathrm{~g} \mathrm{GA}_{3}$ lalu ditambah air sebanyak $1 \mathrm{~L}$ sehingga larutan stok tersebut memiliki konsentrasi 200 ppm. Kemudian melakukan pengenceran sesuai dengan konsentrasi larutan giberelin yang akan digunakan, yaitu $50 \mathrm{ppm}$ yaitu $50 \mathrm{ppm}$, $100 \mathrm{ppm}$ dan $150 \mathrm{ppm}$. Pengenceran konsentrasi $50 \mathrm{ppm}$ dibuat dengan mengambil $250 \mathrm{ml}$ larutan stok dan ditambah air sebanyak $750 \mathrm{ml}$. Konsentrasi $100 \mathrm{ppm}$ yaitu dengan mengambil $500 \mathrm{ml}$ larutan stok lalu ditambah $500 \mathrm{ml}$ air. Konsentrasi 150 ppm dengan mengambil larutan stok sebanyak $750 \mathrm{ml}$ lalu ditambah air sebanyak $250 \mathrm{ml}$. Hasil pengenceran disimpan dalam botol semprot dan diberi label yang sesuai.

Persiapan Lahan. Persiapan lahan dilakukan dengan membersihkan lahan dari gulma dan batu-batuan di sekitar tanaman menggunakan cangkul. Setelah itu memasang label perlakuan pada setiap tanaman.

Pemangkasan. Pemangkasan dilakukan pada cabang yang tidak produktif dengan cara memotong cabang tersebut menggunakan gunting pangkas.

Aplikasi Pupuk Kalium. Pupuk kalium yang digunakan adalah pupuk $\mathrm{KCl}$ dengan dosis pupuk per tanaman adalah $0 \mathrm{~kg}$, $150 \mathrm{~g}, 300 \mathrm{~g}$ dan $450 \mathrm{~g}$. $\mathrm{KCl}$ mengandung $60 \% \mathrm{~K}_{2} \mathrm{O}$ sehingga $\mathrm{K}$ dalam pupuk yang dapat diserap tanaman pada perlakuan secara berturut-turut adalah $0 \mathrm{~g} \mathrm{~K}, 74,68 \mathrm{~g} \mathrm{~K}, 149,36 \mathrm{~g} \mathrm{~K}$ dan 224,04 g K. Pemupukan dilakukan dengan menabur pupuk secara merata di lubang yang dibuat melingkar sekitar tanaman lalu ditutup kompos.

Aplikasi Hormon Giberelin. Hormon giberelin disemprotkan sebanyak 2 kali, yaitu saat bunga mekar sempurna dan saat buah muncul. Penyemprotan dilakukan dengan konsentrasi sesuai perlakuan. Waktu penyemprotan yaitu saat sore hari antara jam 15.30-17.00 WIB.

Pemeliharaan Tanaman. Pemeliharaan tanaman meliputi pemangkasan, pembungkusan buah dan pengendalian OPT. Pemangkasan dilakukan pada cabang yang tidak produktif. Pembungkusan buah dilakukan saat buah sudah berumur kurang lebih 45 hari setelah muncul buah. Pengendalian OPT seperti hama atau penyakit dilakukan menggunakan pestisida.

Pemanenan. Pemanenan dilakukan 110-120 hari setelah bunga mekar atau minimal 45 hari setelah pembungkusan. Panen dilakukan saat kulit buah berwarna kuning mengkilap dengan warna tepi lingsir kuning. Pemanenan dilakukan dengan memotong tangkai buah menggunakan gunting buah. Buah belimbing yang siap panen adalah buah yang ukurannya besar(maksimal), telah matang dan berubah warna dari hijau menjadi putih, kuning atau merah sesuai dengan ciri varietasnya. Buah yang dipetik langsung dimasukkan dalam wadah secara hati-hati agar tidak memar atau rusak (BAPPENAS, 2000). Berdasarkan SNI nomor 01-4491-1998, buah belimbing manis yang bagus adalah buah belimbing yang berbentuk sempurna, tidak memiliki memar, tidak keriput, bebas kotoran dan sisa bagian tanaman yang lain, bebas dari bau dan rasa asing selain aroma atau bau dan rasa khas belimbing dan memiliki tingkat kematangan buah yang layak untuk dipanen. Variabel

pengamatan. terdiri dari berat segar buah (gram), panjang buah $(\mathrm{cm})$, diameter buah $(\mathrm{cm})$, kadar air buah $(\%)$, total padatan terlarut ( ${ }^{\circ}$ brix) dan kandungan sukrosa $(\mathrm{mg} / \mathrm{g})$.

\section{HASIL DAN PEMBAHASAN}

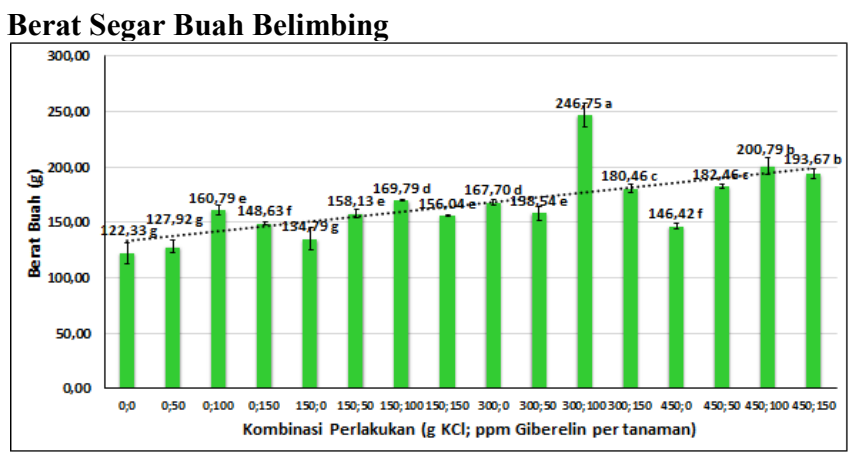

Gambar 1. Pengaruh Kombinasi Perlakuan Pupuk Kalium dan Hormon Giberelin terhadap Berat Segar Buah (gram) 
Variabel yang dapat digunakan sebagai penentu keberhasilan dalam meningkatkan kuantitas dan kualitas buah Belimbing Tasikmadu yaitu produksi buah belimbing. Indikator produksi yang dapat digunakan adalah berat segar buah. Hal tersebut dikarenakan buah belimbing dijual dan dikonsumsi dalam kondisi segar. Hasil penelitian menunjukan bahwa kombinasi perlakuan 300 gram $\mathrm{KCl} /$ tanaman dan $100 \mathrm{ppm}$ konsentrasi giberelin dapat menghasilkan buah terberat yaitu 246,75 gram/buah.

\section{Panjang dan Diameter Buah Belimbing}

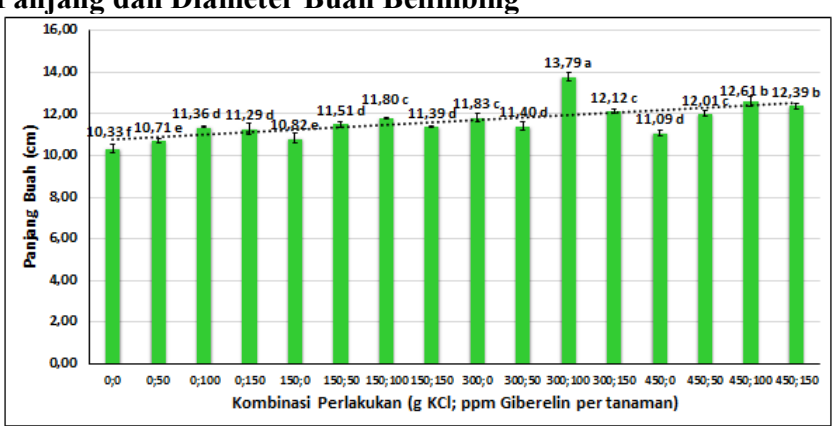

Gambar 2. Pengaruh Kombinasi Perlakuan Pupuk Kalium dan Hormon Giberelin terhadap Panjang Buah $(\mathrm{cm})$

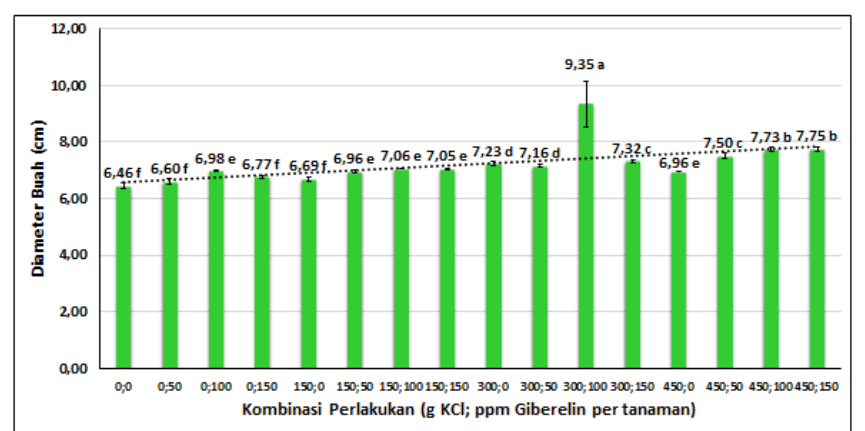

Gambar 3. Pengaruh Kombinasi Perlakuan Pupuk Kalium dan Hormon Giberelin terhadap Diameter Buah $(\mathrm{cm})$

Buah yang memiliki berat segar terberat ternyata memiliki ukuran buah yang besar. Terlihat bahwa buah terberat pada kombinasi perlakuan pupuk $\mathrm{KCl} 300$ gram/tanaman dan konsentrasi giberelin $100 \mathrm{ppm}$ juga memiliki panjang dan diameter yang paling besar yaitu panjang $13,79 \mathrm{~cm}$ (Gambar 2.) dan diameter 9,35 cm (Gambar 3.).

\section{Kadar Air Buah Belimbing}

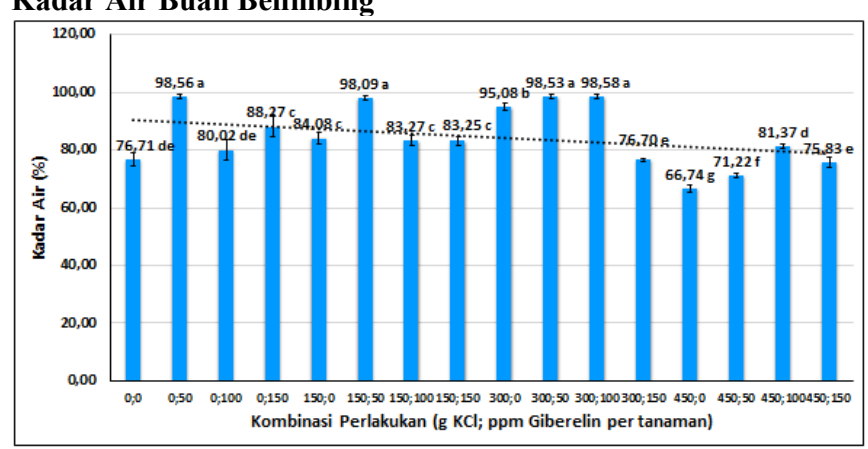

Gambar 4. Pengaruh Kombinasi Perlakuan Pupuk Kalium dan Hormon Giberelin terhadap Kadar Air Buah (\%)

Kombinasi perlakuan pupuk $\mathrm{KCl}$ sebesar 300 gram/tanaman dan konsentrasi hormon giberelin $100 \mathrm{ppm}$ juga memberikan nilai kadar air tertinggi yaitu sebesar $98,58 \%$.
Total Padatan Terlarut dan Kandungan Sukrosa Buah Belimbing

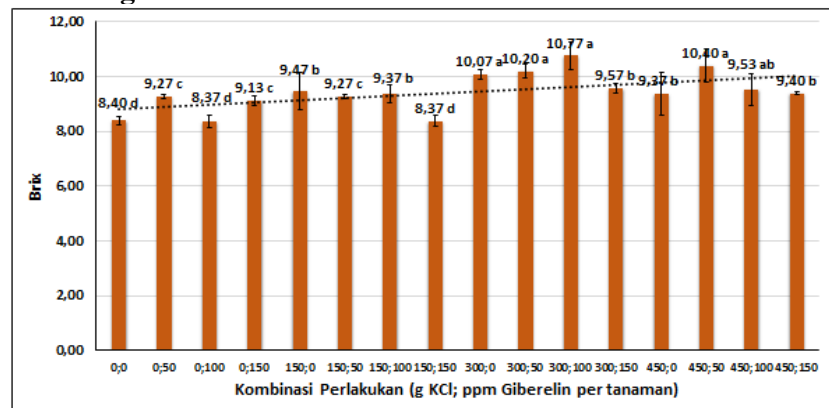

Gambar 5. Pengaruh Kombinasi Perlakuan Pupuk Kalium dan Hormon Giberelin terhadap Total Padatan Terlarut ( ${ }^{\mathrm{b} b r i x)}$

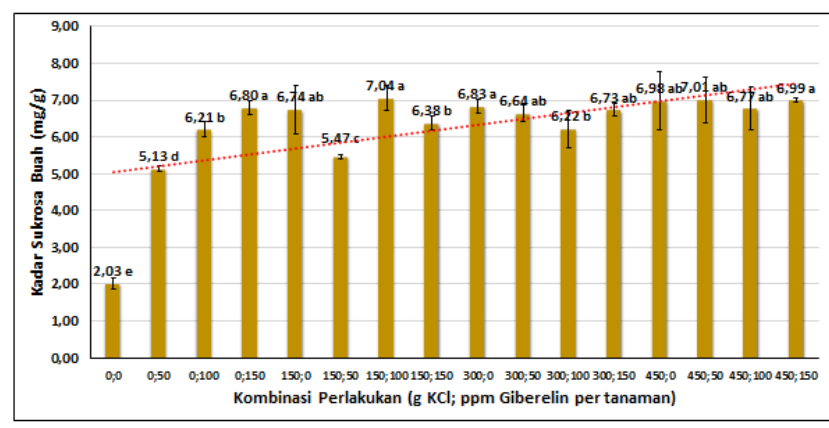

Gambar 6. Pengaruh Kombinasi Perlakuan Pupuk Kalium dan Hormon Giberelin terhadap Kandungan Sukrosa Buah $(\mathrm{mg} / \mathrm{g})$

Total padatan terlarut tertinggi terdapat pada kombinasi perlakuan pupuk $\mathrm{KCl} 300$ gram/tanaman dan konsentrasi giberelin $100 \mathrm{ppm}$ dengan nilai sebesar $10,77^{0}$ Brix (Gambar 5.), sedangkan nilai kandungan sukrosa tertinggi terdapat pada kombinasi perlakuan pupuk $\mathrm{KCl} 150$ gram/tanaman dan konsentrasi giberelin $100 \mathrm{ppm}$ yaitu sebesar 7,039 mg/g (Gambar 6.).

Pemberian pupuk $\mathrm{KCl}$ dan hormon giberelin mempunyai kecenderungan berpengaruh positif pada berat segar buah, panjang buah dan diameter buah. Menurut Permatasari dkk. (2016), giberelin merupakan hormon tanaman yang mempengaruhi pembelahan dan pembesaran sel. Kadar giberelin dalam tanaman dapat meningkatkan kadar auksin karena giberelin dapat memacu sintesis enzim proteolitik yang dapat melunakkan dinding sel tanaman. Dinding sel yang melunak dapat menyebabkan melepasnya amino triptofan yang merupakan prekursor auksin sehingga auksin meningkat. Auksin berperan dalam pembelahan sel dan giberelin berperan dalam pembentangan sel sehingga sinergisme antara auksin dan giberelin tersebut dapat menambah ukuran sel. Berdasarkan hal tersebut maka penambahan hormon giberelin secara eksogen dapat menambah ukuran sel akibat adanya pembelahan dan pembentangan sel. Mesah dkk. (2018) juga menyatakan bahwa giberelin pada konsentrasi tertentu dapat meningkatkan turgor dinding sel sehingga dinding sel akan mengalami perenggangan yang mengakibatkan ikatan antara dinding sel melemah. Melemahnya ikatan antar dinding sel tersebut dapat mendorong dinding sel dan membran sel bertambah besar yang akhirnya ukuran sel akan bertambah besar.

Pemberian pupuk $\mathrm{KCl}$ bertujuan untuk menambah unsur hara kalium dalam tanah sehingga dapat mendukung pertumbuhan tanaman. Kalium merupakan unsur hara makro yang dibutuhkan tanaman dalam jumlah yang cukup besar. Kalium dapat membantu fotosintesis tanaman (Anon, 1989). Kekurangan unsur kalium dapat mengurangi laju fotosintesis, pertumbuhan tanaman dan bobot buah yang dihasilkan (Suwanti dkk., 2017). Uliyah dkk. (2017) juga menyatakan bahwa kalium dalam tanaman berfungsi dalam proses pembentukan gula dan pati, translokasi gula, aktivator enzim dan mempengaruhi pergerakan stomata. Ion $\mathrm{K}^{+}$ dalam sel tanaman dapat meningkatkan turgiditas sel penjaga maka 
stomata daun akan membuka dan proses fotosintesis akan berlangsung. Secara tidak langsung kalium membantu proses terjadinya fotosintesis. Fotosintesis akan menghasilkan fotosintat yang berupa karbohidrat. Hasil fotosintesis tersebut akan ditranslokasikan ke seluruh bagian tanaman yang membutuhkan dan akan disimpan sebagai cadangan makan pada bagian-bagian tertentu tanaman seperti buah. Ketersediaan kalium yang cukup bagi tanaman akan mendukung terjadinya fotosintesis dengan baik. Oleh sebab itu, laju fotosintesis yang tinggi dapat memacu banyaknya asimilat yang dihasilkan oleh tanaman sehingga dapat mendukung pertumbuhan dan produksi tanaman.

Selain dapat memberikan berat dan ukuran buah yang besar, pemberian pupuk $\mathrm{KCl}$ dan hormon giberelin secara eksogen dapat meningkatkan kadar air buah karena diketahui bahwa kalium dan giberelin dapat meningkatkan turgor sel tanaman sehingga dapat menyebabkan buah juga memiliki kadar air yang tinggi. Uliyah dkk. (2017) menyatakan bahwa kalium yang diserap tanaman berfungsi dalam pembentukan protein dan karbohidrat serta menjaga turgor tanaman. Sedangkan giberelin sendiri dapat meningkatkan turgor dinding sel tanaman agar sel tanaman dapat bertambah ukurannya (Mesah dkk., 2018).

Belimbing yang memiliki kualitas bagus adalah belimbing yang memiliki tingkat kemanisan yang tinggi. Pengukuran tingkat kemanisan buah belimbing dapat dilakukan dengan mengukur total padatan terlarut dan kandungan sukrosa buah. Berdasarkan pengukuran total padatan terlarut dan kandungan sukrosa buah (Gambar 4.7 dan Gambar 4.8) memiliki tingkat kemanisan yang berbeda. Perbedaan nilai tersebut terjadi karena padatan terlarut dan sukrosa tersebut berbeda sehingga menunjukan hasil yang berbeda. Total padatan terlarut buah merupakan total semua padatan yang terlarut dalam air buah. Komponen padatan terlarut tersebut terdiri dari total gula, pigmen, asam-asam organik dan protein (Ismawati dkk., 2016). Sedangkan sukrosa merupakan senyawa heterodisakarida hasil dari penggabungan dua buah karbon monosakarida yaitu glukosa dan fruktosa (Hidayanto dkk., 2010). Berdasarkan pernyataan tersebut terlihat bahwa padatan terlarut dan sukrosa jelas berbeda karena sukrosa merupakan jenis gula sedangkan padatan terlarut tidak hanya gula yang diukur namun juga ada komponen lain walaupun kedua variabel tersebut dapat digunakan untuk mengukur tingkat kemanisan buah. Kemanisan buah juga dipengaruhi unsur kalium, karena unsur kalium dapat meningkatkan kualitas tanaman terutama pada tingkat kemanisan buah. Kalium membantu tanaman mentranslokasikan gula pada bagian tanaman yang membutuhkan. Peningkatan serapan unsur hara kalium oleh tanaman dapat membantu meningkatkan kadar gula pada tanaman (Firmansyah dkk., 2018), selain kalium membantu proses pembentukan gula dan pati serta membantu translokasi gula tersebut (Uliyah dkk., 2017).

\section{KESIMPULAN}

Pemberian pupuk $\mathrm{KCl} 300$ gram/tanaman dan konsentrasi hormon giberelin $100 \mathrm{ppm}$ dapat memberikan hasil terbaik.

\section{DAFTAR PUSTAKA}

Badan Pusat Statistik. 2017. Kabupaten Tuban dalam Angka 2017. Bandung: CV. Azka Putra Pratama.

BAPPENAS. 2000. Budidaya Tanaman Buah Belimbing. Dinas Pertanian D.I Yogjakarta.

Firmansyah, M. A., W. A. Nugroho dan Suparman. 2018. Pengaruh Varietas dan Paket Pemupukan pada Fase Produktif terhadap Kualitas Melon (Cucumis melo L.) di Quartzipsamments. Hortikultura Indonesia, 9(2): 93-102.
Gubali, H. N., F. Zakaria dan A. S. Harun. 2017. Induksi Partenokarpi pada Dua Varietas Mentimun (Cucumis sativus L.) dengan Giberelin. Prosiding Seminar Nasional Pengembangan Teknologi Pertanian, 22-27.

Hidayanto, E., A. Rofiq dan H. Sugito. 2010. Aplikasi Portable Brix Meter untuk Pengukuran Indeks Bias. Berkala Fisika, 13(4): 113-118.

Ismawati, N., Nurwantoro dan Y. B. Pramono. 2016. Nilai pH, Total Padatan Terlarut dan Sifat Sensoris Yoghurt dengan Penambahan Ekstrak Bit (Beta vulgaris L.). Aplikasi Teknologi Panen, 5(3): 89-93.

Mesah, R., E. St. O. Nguru dan Y. R. Y. Gandut. 2018. Pengaruh Konsentrasi Zat Pengatur Tumbuh Giberelin GibGro 10 SP terhadap Pertumbuhan dan Hasil Tanaman Terung (Solanum melongena L.). Agrisa, 7(2): 254-265.

Permatasari, D. A., Y. S. Rahayu dan E. Ratnasari. 2016. Pengaruh Pemberian Hormon Giberelin terhadap Pertumbuhan Buah secara Partenikarpi pada Tanaman Tomat Varietas Tombatu F1. LenteraBio, 5(1): 25-31.

Sari, E. W. 2013. Faktor-Faktor Penyebab Produksi Perkebunan Belimbing di Kecamatan Palang Kabupaten Tuban. Pendidikan Geofrafi FIS Unesa, 2(2): 200-207.

Simorangkir, C. A., A. Supriyanto, W. E. Murdiono dan E. Nihayati. 2017. Pemberian Pupuk Urin Kelinci (Leporidae) dan $\mathrm{KNO}_{3}$ pada Pertumbuhan dan Hasil Tanaman Stroberi (Fragaria sp.). Produksi Tanaman, 5(5): 782-790.

Suwanti, J. Susilo, M. Baskara dan K. P. Wicaksono. 2017. Respon Pembungaan dan Hasil Tanaman Nanas (Ananas comosus (L.) Merr) cv. Smooth Cayenne terhadap Pengurangan Pemupukan dan Aplikasi Etilen. Produksi Tanaman, 5(8): 1346-1355.

Uliyah, V. N., A. Nugroho dan N. E. Suminarti. 2017. Kajian Variasi Jarak Tanam dan Pemupukan Kalium pada Pertumbuhan dan Hasil Tanaman Jagung Manis (Zea mays saccharata Sturt L.). Produksi Tanaman, 5(12): 2017-2025).

Wibowo, P. 2015. Panduan Praktis Penggunaan Pupuk dan Pestisida untuk Tanaman Buah dan Sayur. Jakarta: Penebar Swadaya.

Widiatmaka, W. Ambarwulan, M. Y. J. Purwanto, Y. Setiawam dan H. Effendi. 2015. Daya Dukung Lingkungan Berbasis Kemampuan Lahan di Tuban Jawa Timur. Manusia dan Lingkungan, 22(2): 247-259. 